\title{
Shrub legume green manure intercropped with maize preceding organic snap bean cultivation
}

\author{
Jhonatan $M$ Goulart ${ }^{1} \mathbb{D}$; José Guilherme M Guerra ${ }^{2} \mathbb{D}$; José Antonio A Espindola ${ }^{2} \mathbb{D}$; Ednaldo da S Araújo \\ DiD; Janaína RC Rouws ${ }^{2} \mathbb{D}$
}

${ }^{1}$ Universidade Federal Rural do Rio de Janeiro (UFRRJ), Seropédica-RJ, Brasil; marinsgoulart@ymail.com; ${ }^{2}$ Embrapa Agrobiologia, Seropédica-RJ, Brasil; guilherme.guerra@embrapa.br; jose.espindola@embrapa.br; ednaldo.araujo@embrapa.br; janaina.rouws@embrapa.br

\begin{abstract}
This study aimed to evaluate strategies for growing pigeon pea and tephrosia intercropped with maize in different spatial arrangements for green manure in organic snap bean farming in succession. The experimental design was a randomized block, in a $2 \times 3+1$ factorial scheme, corresponding to the two species and the cropping system (monocropping; intercropping with sowing in the same row or between rows). The treatments consisted of pigeon pea and tephrosia monocropping, pigeon pea or tephrosia intercropped with maize in the same planting furrow, pigeon pea or tephrosia intercropped with maize between rows, and maize monocropping (control). After cutting the pre-crops, snap beans were sown. The authors verified that the introduction of shrub leguminous plants in intercropping did not interfere with the phytotechnical characteristics of maize. The tephrosia monocropping and the intercropping of this species with maize, regardless of sowing location, provided, respectively, the highest productivities of pods and dry beans of snap beans, compared with pigeon pea pre-cropping.
\end{abstract}

Keywords: Cajanus cajan, Tephrosia sinapou, agroecology, organic production.

\begin{abstract}
RESUMO
Adubação verde com leguminosas arbustivas consorciadas ao milho antecedendo o cultivo orgânico de feijão-vagem

Objetivou-se avaliar estratégias para a introdução de guandu e de tefrósia consorciadas ao milho em diferentes arranjos espaciais para fins de adubação verde no cultivo orgânico de feijão-vagem em sucessão. $\mathrm{O}$ delineamento experimental foi de blocos casualizados, em esquema fatorial $2 \times 3+1$, sendo um fator formado pelas duas espécies e o outro pelos sistemas de manejo (monocultivo; consórcio com semeadura na mesma linha, ou na entrelinha). Destarte, os tratamentos então consistiram de monocultivos de guandu e de tefrósia, guandu ou tefrósia consorciados ao milho no mesmo sulco de plantio e guandu ou tefrósia consorciados ao milho nas entrelinhas, além do monocultivo de milho (controle). Após o corte dos précultivos realizou-se a semeadura de feijão-vagem. Denotou-se que a introdução das leguminosas arbustivas em consórcio não interferiu nas características fitotécnicas do milho. O monocultivo de tefrósia e as estratégias de cultivo consorciado desta espécie com o milho, independentemente da localização da semeadura, proporcionam, respectivamente, as maiores produtividades de vagens e de grãos secos de feijão-vagem, quando comparados aos pré-cultivos respectivos de guandu.
\end{abstract}

Palavras-chave: Cajanus cajan, Tephrosia sinapou, agroecologia, produção orgânica.

\section{Received on January 12, 2021; accepted on July 23, 2021}

$\mathrm{V}$ egetable production is characterized by short cycles and intensive cultural practices. Among these cultural practices, we highlight the crop fertilization, which can be carried out through several sources, depending on local availability of inputs and the adopted cultivation system. In organic production systems, synthetic sources of fertilizers are not allowed, being fundamental to recycle nutrients through composting, the use of previously composted manure and other natural sources of fertilizer.
The use of green fertilizers also contributes towards improving soil fertility and crop nutrition in different cropping systems (Lima Filho et al., 2014). This technique consists of growing plants with productive potential of biomass and soil mulch, being adopted exclusive crops or intercropping schemes (Espindola et al., 2005). After cut and waste decomposition, the nutrients accumulated in the biomass are available, benefiting crops of economic interest cultivated in succession (Silva et al., 2011). The most common species used in this management are vegetables and grass; members of the asteraceous and cruciferous family are also used, though.

Research results related to the use of green manures prior to the cultivation of vegetables or in intercropping demonstrate the beneficial effect of this type of management. Cordeiro et al. (2018) verified that the leguminous green mucuna, provided an increase in cabbage productivity, submitted to organic management, when compared with maize pre-cultivation, 
able to replace the organic mulch fertilization without decreasing the vegetable productivity. In another study, Souza et al. (2019) verified that the pre-cultivation of Crotalaria juncea inoculated with arbuscular mycorrhizal fungi (Glomus clarum) brought benefits to the agronomic performance of sweet potato under field conditions.

Castro et al. (2004) reported that using leguminous in green manure in pre-cultivation and intercropping contributes significantly to $\mathrm{N}$ supply for the eggplant crop and that the amount of $\mathrm{N}$ introduced by biological fixation derived from pre-cultivation green manure and intercropped with eggplant is sufficient to compensate the $\mathrm{N}$ exported by fruit harvest. Vargas et al. (2011) also verified positive effects using this technique, reporting that growing cabbage on shoot mass or whole plant of crotalaria or jack bean reduces the need for mineral-N fertilization by up to $50 \%$.

Even with all the benefits of green manure for the crops, few studies on the use of shrub legumes can be found in literature. This can be associated with the slow growing and long period of these vegetables in the growing areas. In this context, the aim of this study was to evaluate strategies to introduce pigeonpea and tephrosia intercropped with maize in different spatial arrangements for green manure in organic cultivation of snap beans planted in succession.

\section{MATERIAL AND METHODS}

The experiment was carried out at Fazendinha Agroecológica km 47 , located in the municipality of Seropédica, in the metropolitan region of Rio de Janeiro ( $22^{\circ} 46^{\prime} \mathrm{S}, 43^{\circ} 41^{\prime} \mathrm{W}, 33$ $\mathrm{m}$ altitude). The soil in the experimental area was classified as Red Yellow Argisol (Santos et al., 2018). The chemical properties in 0 to $20 \mathrm{~cm}$ layer are: $\mathrm{pH}$ $=6.4 ; \mathrm{Al}^{+++}=0.0 \mathrm{cmol}_{\mathrm{c}} / \mathrm{dm}^{-3} ; \mathrm{Ca}^{++}=$ $3.50 \mathrm{cmol} / \mathrm{dm}^{-3} ; \mathrm{Mg}^{++}=1.10 \mathrm{cmolc}$ $\mathrm{dm}^{-3} ; \mathrm{K}^{+}=90.14 \mathrm{mg} \mathrm{dm}^{-3}$ and available $\mathrm{P}=88.25 \mathrm{mg} \mathrm{dm}^{-3}$, analyzed using the methodology proposed by Nogueira \& Souza (2005). The experimental design used was randomized blocks, in a factorial scheme $2 \times 3+1$, being one factor consisting of two species and the other factor consisting of the management systems (monocropping; intercropping with sowing in the same row, or between rows). Thus, seven treatments were evaluated: pigeon pea monocropping; pigeon pea intercropped with maize in the same furrow; pigeon pea intercropped with maize between rows; tephrosia monocropping; tephrosia intercropped with maize in the same furrow; tephrosia intercropped with maize between rows and maize BRS Caatingueiro monocropping (control). Each plot consisted of an area covering $25.6 \mathrm{~m}^{2}$, measuring $8.0 \times 3.20 \mathrm{~m}$.

In this stage, fertilization was performed only for the maize crop, using $2.5 \mathrm{t} \mathrm{ha}^{-1}$ (corresponding to a total $\mathrm{N}$ supply of $100 \mathrm{~kg} \mathrm{ha}^{-1}$ ), splitted into two applications, $50 \mathrm{~kg} \mathrm{ha}^{-1}$ at planting and $50 \mathrm{~kg} \mathrm{ha}^{-1}$ at top-dressing, 30 days after sowing. The authors used fermented Bokashi compost as fertilizer source, prepared with a mixture of $40 \%$ leucaena leaves and $60 \%$ wheat bran. After weighing, leucaena leaves and wheat bran were mixed and inoculated with an activated and dilute solution containing Lactobacillus plantarum $10^{4}$ $\mathrm{UFC} / \mathrm{mL}$ and Saccharomyces cerevisiae $10^{4} \mathrm{UFC} / \mathrm{mL}$. To prepare the activated solution, we used $50 \mathrm{~mL}$ Embiotic ${ }^{\circledR}$ commercial product, $50 \mathrm{~g}$ brown sugar and $400 \mathrm{~mL}$ water, stored in a plastic bottle for seven days. This activated solution was diluted in 50 liters water during the compost preparation. The solution was added to the mixtures in order to reach from 40 to $50 \%$ moisture, tactilely checked by manually compressing until a stable clod was obtained without crumbling or running out of liquid. Right after, the mixture was packed in a hermetically sealed container for 21 days.

Legumes and maize monocropping and intercropped were sown spaced 0.8 $\mathrm{m}$ between rows and $0.20 \mathrm{~m}$ between plants, totalizing 62,500 plants $\mathrm{ha}^{-1}$ for each species. At 90 days after sowing, maize plants were broken at the base of the ear to favor the growth of intercropped legumes, leaving the ears next to plants to be drought naturally in the field. At 120 days after sowing, the dried ears were harvested and evaluated in relation to agronomic performance in relation to productivity of grains, cob and cob straw. Still in this evaluation, six square meters of maize biomass were sampled, removing a sub-sample which was taken to a forced ventilation oven at $65^{\circ} \mathrm{C}$ to quantify the dry biomass produced and determine the nutrient content. In relation to the leguminous vegetables, 180 days after sowing, six square meters were sampled in order to quantify the green biomass production, taking a subsample to determine dry biomass and nutrient content, using the same procedures described for maize. The procedure to analyze $\mathrm{N}$ in the biomass was based on Kjedahl method, $\mathrm{P}$ using the colorimetric method, $\mathrm{K}$ using flame photometry, $\mathrm{Ca}$ and $\mathrm{Mg}$ by the atomic absorption method, according to the procedures described by Nogueira \& Souza (2005).

After harvesting the dry maize and the total development of legumes, all the material was crushed with the aid of a crusher (model TCP 160) and kept on the soil, and afterwards furrows were opened for sowing snap beans (cv. Novirex) in succession to different pre-crops. The authors used spacing 0.4 $\mathrm{m}$ between rows, density of eight plants per linear meter, totalizing a population of 200,000 plants ha ${ }^{-1}$. We evaluated: number of pods per plant, average pod length, green pod productivity, number of seeds per pod, 100-seed weight and seed productivity. The evaluations were carried out in alternate rows, sampling 16 linear meters from the 4 central lines, where eight linear meters were used for the evaluation of green pods and 8 linear meters were kept to determine dry grain production. Data were submitted to the variance analysis by $\mathrm{F}$ test and, when the results among factors related to intercroppings were significant, we compared the averages using ScottKnott test ( $\mathrm{p} \leq 0.05)$. Data were evaluated using R software (R Core Team, 2021).

\section{RESULTS AND DISCUSSION}

Productivity of dry biomass, grains, cob and cob straw of the maize crop (Tables 1 and 2) were not influenced 
Table 1. Productivity of grains, cob and cob straw and dry biomass of maize. Seropédica, Embrapa Agrobiologia, 2019.

\begin{tabular}{lcccc}
\hline \multirow{2}{*}{ Treatment } & \multicolumn{4}{c}{ Productivity $\left(\mathbf{k g ~ h a}^{-1}\right)$} \\
\cline { 2 - 5 } & Grains & Cob & Cob straw & Dry biomass \\
\hline Maize + pigeon pea row & $4522.34 \mathrm{~A}$ & $573.81 \mathrm{~A}$ & $776.36 \mathrm{~A}$ & $4250.0 \mathrm{~A}$ \\
Maize + pigeon pea between row & $4029.00 \mathrm{~A}$ & $549.80 \mathrm{~A}$ & $832.51 \mathrm{~A}$ & $3906.2 \mathrm{~A}$ \\
Maize + tephrosia row & $4222.01 \mathrm{~A}$ & $568.15 \mathrm{~A}$ & $877.53 \mathrm{~A}$ & $3156.2 \mathrm{~A}$ \\
Maize + tephrosia between rows & $4954.40 \mathrm{~A}$ & $636.71 \mathrm{~A}$ & $870.01 \mathrm{~A}$ & $4656.2 \mathrm{~A}$ \\
Maize monocropping & $4212.53 \mathrm{~A}$ & $536.84 \mathrm{~A}$ & $771.92 \mathrm{~A}$ & $2968.7 \mathrm{~A}$ \\
\hline CV $(\%)$ & 16.50 & 12.10 & 12.10 & 22.55 \\
\hline
\end{tabular}

Averages followed by the same letter in the same column do not differ from each other by the Scott-Knott test and analysis of variance $\mathrm{F}$ test at $5 \%$ probability.

Table 2. Productivity of grains, cob and cob straw and corn dry biomass in general averages of the intercrops. Seropédica, Embrapa Agrobiologia, 2019.

\begin{tabular}{lcccc}
\hline \multirow{2}{*}{ Pre-cultivation } & \multicolumn{4}{c}{ Productivity $\left(\mathbf{k g ~ h a} \mathbf{-}^{-1}\right)$} \\
\cline { 2 - 5 } & Grains & Cob & Cob straw & Dry biomass \\
\hline Maize + pigeon pea & $4275.60 \mathrm{~A}$ & $570.98 \mathrm{~A}$ & $826.95 \mathrm{~A}$ & $4078.12 \mathrm{~A}$ \\
Maize + tephrosia & $4588.20 \mathrm{~A}$ & $593.26 \mathrm{~A}$ & $851.26 \mathrm{~A}$ & $3906.25 \mathrm{~A}$ \\
\hline Management & & & & \\
\hline Row & $4372.17 \mathrm{~A}$ & $561.81 \mathrm{~A}$ & $804.44 \mathrm{~A}$ & $3703.12 \mathrm{~A}$ \\
Between rows & $4491.69 \mathrm{~A}$ & $602.43 \mathrm{~A}$ & $873.77 \mathrm{~A}$ & $4281.25 \mathrm{~A}$ \\
\hline CV $(\%)$ & 15.95 & 11.20 & 9.75 & 23.40 \\
\hline Ave & & & & \\
\hline
\end{tabular}

Averages followed by the same letter in the same column do not differ from each other by analysis of variance $\mathrm{F}$ test for cultivation and by the Scott-Knott test for management, at 5\% probablility.

Table 3. Biomass productivity of legumes in monocropping and intercropped with maize. Seropédica, Embrapa Agrobiologia, 2019.

\begin{tabular}{|c|c|c|c|c|}
\hline \multirow{2}{*}{ Pre-cultivation } & \multicolumn{3}{|c|}{ Biomass of legumes $\left(\mathrm{kg} \mathrm{ha}^{-1}\right)$} & \multirow{2}{*}{$\begin{array}{l}\text { Maize + Legumes } \\
\text { (Total) }\end{array}$} \\
\hline & Leaf & Stem & Stem+leaf & \\
\hline Pigeon pea & $2788.72 \mathrm{~A}$ & $6705.78 \mathrm{~A}$ & $9494.51 \mathrm{~A}$ & $12213.25 \mathrm{~A}$ \\
\hline Tephrosia & $3319.53 \mathrm{~A}$ & $5295.90 \mathrm{~B}$ & $8615.44 \mathrm{~A}$ & $11219.60 \mathrm{~A}$ \\
\hline \multicolumn{5}{|l|}{ Management } \\
\hline Row & $2972.10 \mathrm{~A}$ & $5033.89 \mathrm{~B}$ & $8006.0 \mathrm{~B}$ & $11709.1 \mathrm{~A}$ \\
\hline Between rows & $2836.92 \mathrm{~A}$ & $4395.98 \mathrm{~B}$ & $7032.9 \mathrm{~B}$ & $11514.1 \mathrm{~A}$ \\
\hline Monocropping & $3356.35 \mathrm{~A}$ & $8572.66 \mathrm{~A}$ & $11926.0 \mathrm{~A}$ & $11926.0 \mathrm{~A}$ \\
\hline $\mathrm{CV}(\%)$ & 23.00 & 21.00 & 20.60 & 16.40 \\
\hline
\end{tabular}

Averages followed by the same letter in the same column do not differ from each other by analysis of variance $\mathrm{F}$ test for cultivation and by the Scott-Knott test for management, at $5 \%$ probablility.

by the legume crops in the cultivation system, regardless of the spatial arrangement adopted. We verified that simultaneous planting of pigeon pea and tephrosia shrub legumes in the maize cultivation system is an advantageous alternative for the management of green manure in agricultural systems, since in the same area it is possible to obtain an income with the crop of economic interest, without reduction of productivity, and to produce a biomass rich in $\mathrm{N}$ through the legume insertion. Other studies related to maize intercropped with legumes, mainly the herbaceous, show benefits of the intercropping system. Santos et al. (2016), evaluating different arrangements between cultivar BRS Caatingueiro and cowpea beans, verified that cowpea bean sown in the same pit is the best arrangement for maize and that the intercropping cultivations provided greater agronomic advantages comparing with monocropping. In another study, Perin et al. (2007) reported that the snap beans intercropped with maize, when sowing in the same row, simultaneously, do not affect the production of green corn and grain corn in the organic production system, providing additional biomass in the system. 
Table 4. Contents and accumulated amounts of $\mathrm{N}$ of legumes in monocropping and intercropped with maize. Seropédica, Embrapa Agrobiologia, 2019.

\begin{tabular}{|c|c|c|c|c|c|}
\hline \multirow[t]{2}{*}{ Pre-cultivation } & \multicolumn{2}{|c|}{$\begin{array}{c}N \text { content } \\
\left(\mathrm{g} \mathrm{kg}^{-1}\right)\end{array}$} & \multicolumn{3}{|c|}{$\begin{array}{c}\begin{array}{c}\text { Accumulated amounts of } \mathrm{N} \\
\left(\mathrm{kg} \mathrm{ha}^{-1}\right)\end{array} \\
\end{array}$} \\
\hline & Leaf & Stem & Leaf & Stem & Total \\
\hline Pigeon pea & $39.0 \mathrm{~A}$ & $14.8 \mathrm{~A}$ & $109.06 \mathrm{~A}$ & $99.91 \mathrm{~A}$ & $208.98 \mathrm{~A}$ \\
\hline Tephrosia & $38.7 \mathrm{~A}$ & $12.6 \mathrm{~A}$ & $128.06 \mathrm{~A}$ & $68.30 \mathrm{~B}$ & $196.36 \mathrm{~A}$ \\
\hline \multicolumn{6}{|l|}{ Management } \\
\hline Row & $38.7 \mathrm{~A}$ & $13.9 \mathrm{~A}$ & $115.26 \mathrm{~A}$ & $70.02 \mathrm{~B}$ & $185.29 \mathrm{~B}$ \\
\hline Between rows & $39.9 \mathrm{~A}$ & $13.1 \mathrm{~A}$ & $113.12 \mathrm{~A}$ & $58.07 \mathrm{~B}$ & $171.19 \mathrm{~B}$ \\
\hline Monocropping & $37.9 \mathrm{~A}$ & $14.2 \mathrm{~A}$ & $127.30 \mathrm{~A}$ & $124.2 \mathrm{~A}$ & $251.54 \mathrm{~A}$ \\
\hline CV (\%) & 6.75 & 13.30 & 25.70 & 26.00 & 22.95 \\
\hline
\end{tabular}

Averages followed by the same letter in the same column do not differ from each other by analysis of variance $\mathrm{F}$ test for cultivation and by the Scott-Knott test for management, at $5 \%$ probablility.

Table 5. Number of pods per plant, number of seeds per pod, length and productivity of pods cultivar Novirex in succession to legumes in monocropping and intercropped with maize. Seropédica, Embrapa Agrobiologia, 2019.

\begin{tabular}{lcccc}
\hline Pre-cultivation & \multicolumn{4}{c}{ Agronomic traits of snap-beans } \\
\cline { 2 - 5 } & \# pods plant $^{-1}$ & \# seeds pod $^{-1}$ & Length (cm) & Pods (kg ha \\
& -1) \\
\hline Pigeon pea & $8.95 \mathrm{~A}$ & $4.05 \mathrm{~A}$ & $12.65 \mathrm{~A}$ & $6640.62 \mathrm{~B}$ \\
Tephrosia & $10.4 \mathrm{~A}$ & $4.22 \mathrm{~A}$ & $13.00 \mathrm{~A}$ & $9046.35 \mathrm{~A}$ \\
\hline Management & & & & \\
\hline Row & $9.40 \mathrm{~A}$ & $4.26 \mathrm{~A}$ & $12.72 \mathrm{~A}$ & $7252.7 \mathrm{~A}$ \\
Between rows & $9.84 \mathrm{~A}$ & $4.02 \mathrm{~A}$ & $12.73 \mathrm{~A}$ & $7933.9 \mathrm{~A}$ \\
Monocropping & $9.83 \mathrm{~A}$ & $4.13 \mathrm{~A}$ & $13.02 \mathrm{~A}$ & $8343.7 \mathrm{~A}$ \\
\hline CV (\%) & 17.95 & 14.42 & 6.10 & 16.60 \\
\hline Averyyyy
\end{tabular}

Averages followed by the same letter in the same column do not differ from each other by analysis of variance $\mathrm{F}$ test for cultivation and by the Scott-Knott test for management, at $5 \%$ probablility.

For agronomic performance of legumes (Table 3), we noticed that the dry biomass production of pigeon pea and tephrosia was superior in the respective monocroppings, highlighting the competitive effect of maize in relation to legumes. We point out that pigeon pea and tephrosia show slow initial growth, and that shading caused by maize in the intercroppings could have contributed to a lower dry biomass productivity of the legumes when compared with the respective monocroppings. In the study carried out by Gonçalves Júnior et al. (2012), tephrosia, under similar weather conditions, reached a productivity of $11.2 \mathrm{t} \mathrm{ha}^{-1}$ during 12 months of cultivation, being this productivity similar to the ones described in this study, when cultivated in monocropping system.

In relation to the total dry biomass productivity of the monocroppings and the sum of the intercropped species (maize + legumes), the intercroppings had productivities similar to legume monocroppings. As previously mentioned, maize productivity was not influenced by the different spatial arrangements, and through intercroppings it is possible to grow crops of economic interest and also provide some additional biomass with higher $\mathrm{N}$ content to the system.

$\mathrm{N}$ contents in the shoot area of pigeon pea and tephrosia were not influenced by the presence of intercropped maize, regardless of the spatial arrangement of cultivation (Table 4). N concentration in the leaves in both species is higher to the ones found in the stem, reaching a superior value of $65.56 \%$. For $\mathrm{N}$ contents in tephrosia leaves, the results were similar to the ones found by Gonçalves Júnior (2013) under similar climatic conditions, whereas the $\mathrm{N}$ contents in pigeon pea leaves were superior to the ones found by this mentioned author.

In relation to $\mathrm{N}$ accumulated in the shoot dry biomass, we verified that the pigeon pea showed the highest accumulated quantity of this macronutrient in the stem when compared with tephrosia. No differences were observed between the vegetables in relation to $\mathrm{N}$ accumulation in the leaves and to the total amount of $\mathrm{N}$ (leaf + stem). However, the respective pigeon pea and tephrosia monocroppings showed superior quantities of accumulated $\mathrm{N}$ in the stem and total, when compared with the respective intercroppings. We highlight that the quantities of $\mathrm{N}$ accumulated are directly proportional to the amount of dry biomass produced by the species, and that despite the reduction in biomass production of legumes in the intercropping caused by competition from corn, the legumes entered high amounts of $\mathrm{N}$ in the system.

Pod productivity was superior in the treatments which showed tephrosia pre-cultivated (Table 5). The pod productivity in succession to tephrosia monoculture reached $9898.4 \mathrm{~kg} \mathrm{ha}^{-1}$, being superior in up to $40.81 \%$ when compared to cultivation in succession to monoculture of maize, $5859.3 \mathrm{~kg} \mathrm{ha}^{-1}$, demonstrating the beneficial effect of this management practice. The highest productivity of pods associated with tephrosia pre-cultivation in relation to pigeon pea can be related to the kinetics of nutrient release of different species, especially $\mathrm{N}$, as this release may be influenced by the factors stem/leaf ratio and the biochemical composition of these parts (Aita et al., 2014). Carvalho (2012), under similar climatic conditions, reported productivity estimated in $9058 \mathrm{~kg} \mathrm{ha}^{-1}$ of the same cultivar. For number of pods per plant, number of seeds per pod and average length, no differences were observed between treatments. 
Table 6. 100-grain weight and dry grain productivity of cultivar Novirex in succession to legumes in monocropping and intercropped with maize. Seropédica, Embrapa Agrobiologia, 2019.

\begin{tabular}{|c|c|c|c|c|}
\hline \multirow{2}{*}{$\begin{array}{l}\text { Species/ } \\
\text { management }\end{array}$} & \multicolumn{4}{|c|}{ Agronomic traits of snap-beans, 100 -seed weight (g) } \\
\hline & Row & $\begin{array}{l}\text { Between } \\
\text { rows }\end{array}$ & Monocropping & $\begin{array}{l}\text { Overall } \\
\text { average }\end{array}$ \\
\hline Pigeon pea & $26.12 \mathrm{Aa}$ & $25.13 \mathrm{Ba}$ & $26.08 \mathrm{Aa}$ & $25.84 \mathrm{~A}$ \\
\hline Tephrosia & $26.31 \mathrm{Ab}$ & $28.47 \mathrm{Aa}$ & $26.14 \mathrm{Ab}$ & $26.91 \mathrm{~A}$ \\
\hline Overall average & $26.11 \mathrm{a}$ & $26.80 \mathrm{a}$ & $26.11 \mathrm{a}$ & \\
\hline \multirow[t]{2}{*}{ CV $(\%)$} & \multicolumn{4}{|c|}{5.85} \\
\hline & \multicolumn{4}{|c|}{ Dry grain productivity $\left(\mathrm{kg} \mathrm{ha}^{-1}\right)$} \\
\hline Pigeon pea & $1083.6 \mathrm{Ba}$ & $984.01 \mathrm{Bb}$ & $1206.2 \mathrm{Aa}$ & $1201.2 \mathrm{~A}$ \\
\hline Tephrosia & $1413.4 \mathrm{Aa}$ & $1344.3 \mathrm{Aa}$ & $1346.7 \mathrm{Aa}$ & $1258.2 \mathrm{~A}$ \\
\hline Overall average & $1248.5 \mathrm{a}$ & $1164.2 \mathrm{a}$ & $1276.5 \mathrm{a}$ & \\
\hline CV (\%) & \multicolumn{4}{|c|}{15.45} \\
\hline
\end{tabular}

Averages followed by the same letter, lowercase in line (managements) and uppercase in column (legumes), do not differ from each other by Scott-Knott method and analysis of variance $\mathrm{F}$ test at $5 \%$ probablility, respectively.

Productivity of dry grains was superior in different intercroppings with tephrosia when compared with pigeon pea, and no significant differences were observed for leguminous monocropping (Table 6). Productivity of dry grains intercropped was superior in up to $49.28 \%$ when compared to succession with maize monocropping. Under similar climatic conditions, evaluating the effect of planting density on production and quality of organic seeds of three snap beans cultivars, Guedes et al. (2007) verified that the seed productivity of cultivar Novirex in different planting densities ranged from 1096.88 to $1574.50 \mathrm{~kg} \mathrm{ha}^{-1}$, being comparable to the productivities found in this study.

The authors noticed that the introduction of shrub leguminous plants in intercropping did not interfere with the phytotechnical characteristics of maize. Tephrosia monocropping and strategies of intercropped cultivation of this maize species, regardless of sowing location, provided, respectively, the highest productivities of pods and dry grains of snap beans, when compared to the respective pre-cultivation of pigeon pea.

\section{REFERENCES}

AITA, C; GIACOMINI, SJ; CERETTA, CA. 2014. Decomposição e liberação de nutrientes dos resíduos culturais de adubos verdes. In: LIMA FILHO, OF; AMBROSANO, EJ; ROSSI, F; CARLOS, JAD (eds). Adubação verde e plantas de cobertura no Brasil: Fundamentos e práticas. p.227-261.

CARVALHO, JF. 2012. Avaliação de cultivares de feijão-caupi e feijão vagem arbustivo em sistema orgânico de produção. Campos dos Goytacazes: UENF. 75p. (M.Sc. dissertation).

CASTRO, CM; ALVES, BJR; ALMEIDA, DL; RIBEIRO, RLD. 2004. Adubação verde como fonte de nitrogênio para a cultura da berinjela em sistema orgânico. Pesquisa Agropecuária Brasileira 39: 779-785.

CORDEIRO, AAS; RODRIGUES, MB; GONÇALVES JÚNIOR, M; ESPINDOLA, JAA; ARAÚJO, ES; GUERRA, JGM. 2018. Organic cabbage growth using green manure in pre-cultivation and organic top dressing fertilization. Horticultura Brasileira 36: 515-520.

ESPINDOLA, JAA; GUERRA, JGM; POLLI, H; ALMEIDA, DL; ABBOUD, ACS. 2005. Adubação verde com leguminosas. Coleção Saber, 5. Seropédica: Embrapa Agrobiologia.

GONÇALVES JUNIOR, M. 2013. Avaliação agronômica de leguminosas arbustivas usadas para adubação verde nas condições da Baixada Fluminense. Seropédica: UFRRJ. 62p. (M.Sc. dissertation).

GONÇALVES JUNIOR, M; SILVA, AGB;
CORDEIRO, AAS; GUERRA, JGM; ESPINDOLA, JAA; ARAUJO, ES. 2012. Crescimento da leguminosa arbustiva Tefrósia vogelii em sistema orgânico de produção. (Embrapa Agrobiologia. Boletim de Pesquisa e Desenvolvimento, 86).

GUEDES, RE; GUERRA, JGM; RIBEIRO, RLD; COELHO, RG; PAULA, PD; MOREIRA, VF. 2007. Avaliação de cultivares de feijãode-vagem de crescimento determinado sob manejo orgânico, nas condições da baixada fluminense. Seropédica: EMBRAPA-RJ. 4p. (Comunicado Técnico, 102).

LIMA FILHO, OF; AMBROSANO, EJ; ROSSI, F; CARLOS, JAD. 2014. Adubação verde e plantas de cobertura no Brasil: Fundamentos e prática. Brasília: Embrapa. 507p.

NOGUEIRA, ARA; SOUZA, GB. 2005. Manual de laboratórios: Solo, água, nutrição vegetal, nutrição animal e alimentos. São Carlos: Embrapa Pecuária Sudeste, 313p.

PERIN, A; BERNARDO, JT; SANTOS, RHS; FREITAS, GBD. 2007. Desempenho agronômico de milho consorciado com feijão-de-porco em duas épocas de cultivo no sistema orgânico de produção. Ciência e Agrotecnologia 31: 903-908.

R Core Team. 2021. R: A language and environment for statistical computing. $\mathrm{R}$ Foundation for Statistical Computing, Vienna, Austria. URL https://www.R-project.org/.

SANTOS, HG; JACOMINE, PKT; ANJOS, LHC; OLIVEIRA, VA; LUMBRERAS, JF; COELHO, MR; ALMEIDA, JA; ARAUJO FILHO, JC; OLIVEIRA, JB; CUNHA, TJF. 2018. Sistema Brasileiro de Classificação de Solos. 5.ed., Brasília, DF: Embrapa, 353p.

SANTOS, MA; BATISTA, PSC; LOPES, MF; SILVA, MGM; BERTO, ALF. 2016. Desempenho agronômico de milho consorciado com feijão-de-corda em diferentes populações e arranjos de plantas no semiárido mineiro. Revista Agro@mbiente On-line. 10: 201-208.

SILVA, EE; POLLI, H; GUERRA, JGM; MENEZES, ELA; OLIVEIRA, FL; RIBEIRO, RLD. 2011. Sucessão entre cultivos orgânicos de milho e couve consorciados com leguminosas em plantio direto. Horticultura Brasileira 29: 57-62.

SOUZA, JR; MAGALHÃES, RS; RIBEIRO, BN; MINGOTTE, FLC; CASTRO, GSA; GUERRA, JGM; ESPINDOLA, JAA. 2019. Desempenho agronômico da batata-doce em sucessão a milho e crotalária inoculados com fungos micorrízicos. Science and Technology Innovation in Agronomy, 3: 106-114.

VARGAS TO; DINIZ ER; SANTOS RHS; LIMA CTA; URQUIAGA, S; CECON PR. 2011. Influência da biomassa de leguminosas sobre a produção de repolho em dois cultivos consecutivos. Horticultura Brasileira 29: 562-568. 